\title{
TAXATION OF ISLAMIC BANKING TRANSACTIONS
}

\author{
Rusell Stanley Geronimo \\ SyCip Salazar Hernandez \& Gatmaitan in Manila, Philippines
}

\begin{abstract}
The paper examines the juridical character of eight common Islamic banking transactions: murabahah, tawarruq, ijarah, istisna, salam, musharakah or mudaraba, sukuk, and takaful. It then compares each Islamic banking product with an equivalent conventional banking product, examines their differences in terms of transaction design, and shows whether these contractual differences result in differential tax treatment.
\end{abstract}

Keywords: Islamic banking, murabahah, tawarruq, ijarah, istisna, salam, musharakah, mudaraba, sukuk, takaful

\section{INTRODUCTION}

One of the perceived reasons why Islamic finance is underdeveloped in the Philippines is the alleged tax inefficiency of Islamic banking products compared to conventional banking products. Underlying contractual arrangements needed to comply with the financial principles of shariah purportedly result in higher transaction costs under the existing tax regime. This paper investigates this claim by first examining the juridical character of eight common Islamic banking transactions: murabahah, tawarruq, ijarah, istisna, salam, musharakah or mudaraba, sukuk, and takaful. It then compares each Islamic banking product with an equivalent conventional banking product, examines their differences in terms of transaction design, and shows whether these contractual differences result in differential tax treatment.

The findings indicate that the tax inefficiency problem is more nuanced than what existing policy research provides. While the claim is true in the case of murabahah, tawarruq, istisna, salam, and sukuk, it is not so in the case of ijarah, musharakah or mudaraba, and takaful. This paper shows the remaining areas that must be addressed by the prospective Islamic banking regulatory framework in the Philippines to achieve tax neutrality, and ultimately transaction cost parity, in the choice between conventional banking and Islamic banking products.

\section{THE ISLAMIC BANKING MARKET IN THE PHILIPPINES}

The World Bank estimates that the global Islamic finance market is $\$ 3$ trillion. The National Commission on Muslim Filipinos (NCMF) estimates the number of Muslims in the Philippines to be approximately 10.7 million (11\% of the total population) as of 2012 . However, Al-Amanah Islamic Investment Bank of the Philippines (AIIBP) is the only Islamic bank in the country. It is a government-owned and - controlled corporation (GOCC) created in 1973 by Presidential Decree (P. D.) No. 264 (repealed and strengthened by Republic Act [R.A.] No. 6848) to provide financial services 
in Muslim areas, such as Basilan, Cotabato, Lanao del Norte, Lanao del Sur, Palawan, Sulu, TawiTai, Zamboanga del Norte, and Zamboanga del Sur. It is a subsidiary of Development Bank of the Philippines (DBP), also another GOCC. To date, it has yet to operate as a full-fledged Islamic bank.

There is currently no legislative and regulatory framework for Islamic finance in the country. While the General Banking Law of 2000 includes Islamic bank as a distinct banking category, there is no Bangko Sentral ng Pilipinas (BSP) regulation providing for the creation of private Islamic banks or a system for the grant of Islamic banking licenses. As a result, foreign Islamic banks are also unable to establish offshore operations in the Philippines. The Philippines has also to establish a professionalized body of shariah experts who can review and provide advice on shariah-compliant banking products and investments.

One of the perceived reasons why Islamic finance is underdeveloped in the Philippines is the alleged tax inefficiency of Islamic banking products compared to conventional banking products. Underlying contractual arrangements needed to comply with the financial principles of shariah purportedly result in higher transaction costs under the existing tax regime. This paper investigates this claim by first examining the juridical character of eight common Islamic banking transactions: murabahah, tawarruq, ijarah, istisna, salam, musharakah or mudaraba, sukuk, and takaful. It then compares each Islamic banking product with an equivalent conventional banking product, examines their differences in terms of transaction design, and shows whether these contractual differences result in differential tax treatment.

\section{ISLAMIC BANKING TRANSACTIONS}

\subsection{Murabahah}

\subsubsection{Nature of the Transaction}

The murabahah is the economic equivalent of the conventional mortgage-backed loan, but it involves different contractual arrangements and different legal relations. The conventional mortgagebacked loan involves a lender-borrower relationship between bank and client, while a mudarabah involves a vendor-vendee relationship.

Under a conventional mortgage-backed loan, a client who wants to purchase an asset obtains a loan from the bank, and the proceeds are used to purchase the asset. To secure the loan obligation, the client and the bank enter into an ancillary contract of mortgage, with the client as mortgagor and the bank as mortgagee. The asset covered by the mortgage may or may not be the asset which is the subject of the purchase. If the client defaults, the bank forecloses the mortgage. The proceeds of the foreclosure sale are then applied to the satisfaction of the loan obligation. Hence, the mortgagebacked loan involves three contracts: (1) the contract of sale between the client and the vendor of the asset, (2) the contract of loan between the client and bank, and (3) the contract of mortgage, also between the client and bank.

Under murabahah, the bank purchases the asset and then sells the asset to the client at a profit. While the mortgage-backed loan involves three contracts (and only one sales contract), the murabahah involves two sales contracts: (1) the contract of sale between the bank and vendor, and (2) the contract of sale between the bank and the client. The first contract is a spot sale (i.e. the total price is immediately paid), while the second contract involves an installment sale. 
In order to assure the bank that the client will purchase the asset, the client must sign a "purchase instruction with promise to purchase" or some other undertaking that will legally obligate him to enter into an installment sale after the execution of the first contract of sale. If the bank approves the transaction, the bank then appoints the client as an agent, under a special contract of agency (wakalah), to purchase the asset from the vendor. When the bank and client execute the installment sale, title is immediately transferred to the client.

The total price in the installment sale has two components: the total cost of the asset under the first contract of sale, and the profit component. The schedule of deferred payments in the installment sale is economically equivalent to the amortization schedule of the mortgage-backed loan, while the profit component in the installment sale is the economic equivalent of interest payment in the loan.

\subsubsection{Differential Tax Treatment}

Income Tax. Under a conventional mortgage-backed loan, the bank obtains income in the form of interest. This forms part of the bank's gross income, which for domestic banks is subject to the regular corporate income tax rate of $30 \%$.

Under mudarabah, the bank obtains income in the form of gain from dealings in property. Accordingly, it is important to distinguish whether this gain is an ordinary gain or a capital gain. This distinction depends on whether the object of sale is an ordinary asset or a capital asset. Since the bank buys the asset for the purpose of selling it at profit, it constitutes "property held by the taxpayer primarily for sale to customers in the ordinary course of his trade or business." Hence, the object of sale from bank to client is an ordinary asset, and the gain from the sale is an ordinary gain. Being an ordinary gain, it forms part of the bank's gross income, also subject to the regular corporate income tax rate of $30 \%$.

The similarity ends here. Since the mudarabah involves an installment sale, it is subject to the rule on deferred payments under Section 49(A) and (B) of the NIRC. If the object of the mudarabah is personal property, the proportion of the price constituting the gain is taxed in the year of actual receipt, whether the accounting method of the bank is cash basis or accrual basis. The same rule applies if the object is real property, and the initial payment does not exceed $25 \%$ of the total selling price. On the other hand, if the initial payment exceeds $25 \%$, the gain is taxed based on the bank's accounting method - i.e., in the year of actual receipt if the bank employs cash basis, and in the year when the gain meets the All-Events Test if the bank employs accrual basis.

If the client fails to pay the bank, different tax implications also arise. Under the conventional mortgage-backed loan, the bank may apply for a judicial or extrajudicial foreclosure of property. The proceeds from the foreclosure sale result in bank income tax liability depending on whether the borrower avails of his right of redemption and whether the bank is the purchaser in the foreclosure sale. If the borrower redeems the property, then title to the property does not pass from the borrower to the purchaser, and therefore no capital gain is due on the proceeds of the foreclosure sale. However, if the borrower does not redeem the property, then title to the property passes from the borrower to the purchaser. If the bank is not the purchaser, no additional income tax liability is due from the bank other than the tax on the portion of the foreclosure proceeds representing interest payment under the loan. If the bank is purchaser, the property forms part of the bank's Real and Other Properties Owned or Acquired (ROPOA), which are in the nature of capital assets because they are not held primarily for sale in the ordinary course of business, nor are they real properties used in the business of banking. Consequently, when the bank subsequently sells the property un- 
der ROPOA, the gain is in the nature of capital gain. If the property under ROPOA is real property, the capital gain is subject to final capital gains tax of $6 \%$ of fair market value or gross selling price, whichever is higher. However, if the property under ROPOA is personal property, the net capital gain forms part of the gross income and is taxable at the regular corporate income tax rate of $30 \%$ of taxable income. ${ }^{1}$

Under murabahah, the bank as seller may avail of the remedies of an unpaid seller. In case of rescission, no tax liability on the ordinary gain in the installment sale arises because the parties restore what they have given under the sale. Since the property is returned to the bank, it now forms part of ROPOA, and is therefore already in the nature of a capital asset because it is no longer "property held by the taxpayer primarily for sale to customers in the ordinary course of his trade or business." Hence, if the bank subsequently sells the property, the gain is in the nature of a capital gain. Again, if the property is real estate, it is subject to final capital gains tax of $6 \%$ of fair market value or gross selling price, whichever is higher, and if it is personal property, the net capital gain forms part of the gross income, taxable at the regular corporate income tax rate of 30\% of taxable income.

Gross Receipts Tax. Gross receipts on banking services are exempt from Value-Added Tax (VAT), but are subject to Gross Receipts Tax (GRT) under Section 121 of the NIRC, as amended by R.A. No. 9337 . Under the conventional mortgage-backed loan, the interest is subject to $5 \%$ of gross receipts if the maturity period is 5 years or less, and $1 \%$ if the maturity period is more than 5 years. On the other hand, under murabahah, the gain constitutes "profits from exchange", which are taxable at $7 \%$ of the gross receipts.

Documentary Stamps Tax. A conventional mortgage-backed loan is subject to the following: (i) DST on Loan Agreement under Section 179 of NIRC, at P1 per P200, and (ii) DST on Mortgage under Section 195, at P20 for P5,000 or less, and at P10 on each P5,000 in excess of P5,000.

On the other hand, the murabahah is subject to the following: (i) DST on Deeds of Sale and Conveyances of Real Property, from Vendor to Bank, under Section 196, at P15 if consideration is P1,000 or less, and P15 on each P1,000 in excess of P1,000; (ii) DST on Deeds of Sale and Conveyances of Real Property, from Bank to Client; and (iii) DST on Powers of Attorney under Section 193 of NIRC, in connection with the execution of wakala, at P5.

Local Taxation. Interest under the conventional mortgage-backed loan and gain from the murabahah are included in the gross receipts of banks for the purpose of imposing Local Business Tax under the Local Government Code. The tax rates may vary depending on the local tax ordinance, but the maximum imposable by municipalities is $50 \%$ of $1 \%$ of gross receipts for preceding calendar year, and the maximum imposable by cities and municipalities within Metro Manila is $75 \%$ of $1 \%$ of gross receipts for the preceding calendar year.

A conventional mortgage-backed loan does not involve transfer of title to and from the bank, except in case of foreclosure sale when the bank is the winning bidder. The murabahah, on the other hand, involves transfer of title from the vendor to the bank, and from the bank to the client. This results in two taxable transactions for the corresponding two instances of transfer of real property ownership under Section 135 of the Local Government Code, imposable by the province where the property is located, at maximum of $50 \%$ of $1 \%$ of the total consideration.

$1 \quad$ Supreme Transliner, Inc. vs. BPI Family Savings Bank, Inc., G.R. No. 165837, 25 February 2011. 


\subsection{Sukuk}

\subsubsection{Nature of the Transaction}

Sukuk is the economic equivalent of a conventional corporate bond. Through a corporate bond, a corporation in need of long-term financing for a project requiring significant amounts of investment issues a bond to the public, subject to registration with the Securities and Exchange Commission. An investor subscribes to the bond issuance, and the proceeds are turned over to the corporation for use in funding the project. By holding the bond, the holder is entitled to periodic interest income, in the form of coupon payments. The bondholders have no claim in a specific asset of the corporation, even if the purpose of the issuance is to fund a specific project.

In contrast, a sukuk requires the setting up of a Special Purpose Vehicle (SPV) by the corporation in need of public financing. The SPV, in turn, raises cash for the corporation by issuing certificates or instruments to investors. The SPV then uses the proceeds to purchase the asset from the corporation, and then leases back the asset to the corporation. Each holder has a proportional interest in the asset owned by the SPV. The corporation, in leasing the asset, pays periodic rental payments to the SPV. The SPV then turns over the rent to the bondholders. This rent constitutes their profit (not interest) on the instrument.

In the conventional corporate bond, no SPV is required, and therefore no lease contract is created between the issuer corporation and the SPV. The corporate bond does not bestow beneficial ownership of the assets to the holder, while the sukuk provides pro-rata ownership of the asset to the holders.

\subsubsection{Differential Tax Treatment}

Income Tax.

(i) Equity or debt instrument.

The income tax treatment of sukuk depends on whether it is classified as equity or debt instrument. While a corporate bond is in the nature of a debt instrument, a sukuk is a form of hybrid security that exhibits qualities from both debt and equity instruments. However, the NIRC does not provide a unique tax treatment for hybrid securities, hence it is imperative that a financial instrument should have only one tax classification, depending on the dominant features of the instrument.

A sukuk is closer to being an equity instrument because the sukuk-holders have ownership interest in the asset held by the SPV. The profit on the instrument is based on the rental income from the asset. The returns on the instrument are not guaranteed, since the risk is shared between the corporate issuer and the sukuk-holder. The only factor that makes sukuks similar to bonds is the fact that it expires, but this is also true for some types of redeemable shares and preferred shares. Hence, a sukuk should be treated similar to a share of stock.

\section{(ii) Income tax treatment of corporate bond.}

A holder of a corporate bond has three possible sources of income: (i) interest on the bond, (ii) trading income before maturity, and (iii) amounts received by the holder upon the retirement of the bond. First, interest on the bond is not subject to the final withholding tax of $20 \%$ because the corporate bond does not constitute "currency bank deposit and yield or any other monetary benefit from deposit substitutes and from trust funds and similar arrangements." Instead, the interest is 
included in the gross income of a taxpayer, subject to the regular income tax rate, which is $5-32 \%$ in the case of resident individuals and $30 \%$ in the case of domestic corporations.

Second, trading income before maturity is taxable depending on the bond's original tenor. If the maturity is more than 5 years, the trading income is excluded from gross income. Otherwise, the trading income is taxable. The bond is an ordinary asset if it is a "property held by the taxpayer primarily for sale to customers in the ordinary course of his trade or business", such as in the case of a dealer in securities. The bond is a capital asset if otherwise. If it is an ordinary asset, the trading income constitutes ordinary gain, which forms part of the gross income, subject to the regular income tax rate. If the bond is a capital asset, the trading income constitutes capital gain, and the net capital again (i.e. capital gain less capital loss during the taxable year) forms part of the gross income, subject to the regular income tax rate.

Third, amounts received by the holder upon the retirement of the bond are considered amounts received in exchange of the bond. Hence, the tax treatment is the same as trading income on the bond, which is taxable depending on the bond's original tenor, same as in the previous paragraph.

\section{(iii) Income tax treatment of sukuk.}

A holder of sukuk has two possible sources of income: (i) periodic profit on the sukuk instrument, and (ii) trading income. We have classified sukuk as equity instruments. Therefore, the periodic profit is in the nature of dividends, while the trading income is in the nature of gains on sale of shares. Hence, the periodic profit on the sukuk instrument is subject to the final withholding tax of $10 \%$. On the other hand, the tax on trading income depends on whether the sukuk is traded through the local exchange, and whether the sukuk constitutes an ordinary asset or capital asset in the hands of the holder. If the sukuk trades through the local exchange, the sale is subject to the Stock Transaction Tax (STT), which is $1 \frac{1}{2}$ of $1 \%$ of the gross selling price. If the sukuk does not trade through the local exchange, and the sukuk is an ordinary asset in the hands of the holder, the gain from the sale constitutes an ordinary gain, which is taxable at the regular income tax rate. If it is a capital asset, the gain constitutes a capital gain, which is subject to a final capital gains tax of 5\% of the first P100,000 of the net capital gains, and $10 \%$ in excess thereof.

The presence of the SPV provides an additional corporate layer that increases the transaction cost of the issuance of sukuk. Since the SPV purchases the asset and leases it back to the corporation in need of financing, the rental income obtained from the corporation is also subject to the regular income tax rate of $30 \%$.

Documentary Stamps Tax. A corporate bond is subject to DST on debt instruments under Section 179 of the NIRC, which is at P1 per P200, or fraction thereof, of the issue price. On the other hand, a sukuk, being a hybrid security that is closer to being an equity than a debt instrument, is subject to the following: (i) DST on original issue of shares of stock under Section 174 of NIRC, which is at P1 per P200, or fraction thereof, of the par value, and (ii) DST on sale of shares under Section 175 of the NIRC, which is at P0.75 per P200, or fraction thereof, of the par value.

\subsection{Takaful}

\subsubsection{Nature of the Transaction}

Takaful is the economic equivalent of insurance. Through a conventional insurance product, a person who wants to insure life or property enters into a contract of indemnity with an insurer, whereby the 
insured pays premiums to the insurer and the insurer indemnifies the insured or his beneficiary for any damage, loss or liability arising from an unknown or contingent event. The insurer pools the premiums from the insured, invests the premium income in various investment assets, and makes the fund selfsustaining and financially viable to pay out liabilities in the future. The contract of insurance does not obligate the insurer to distribute surplus profits from the investments, unless there is a stipulation to the contrary. The insured also has no automatic obligation to make additional premium contributions beyond the stipulated amounts when there is deficiency in the funds to satisfy the insurance claims.

A takaful is similar to conventional insurance products, but with five unique features. First, the insured are members of a pooled investment vehicle. Second, the pooled investment vehicle is operated by a fund manager, which receives commissions or fees for managing the funds of the members. Hence, the pooled investment vehicle is the real insurer, not the fund manager, and the vehicle is an association of all the insured. This setup is similar to mutual insurance schemes allowed in the Insurance Code, and said pooled investment vehicles are analogous to cooperatives. Third, the insured members have a right to surplus profits from the pooled investment vehicles. Fourth, in case of deficiency, the insured members have the obligation to make additional contributions to meet the insurance claims. Finally, the fund manager may only invest in shariah-compliant products.

In short, takaful is legally identical to cooperative insurance. There is no regulatory obstacle for the creation and offering of takaful, other than the prohibition for banks to directly engage in an insurance business under the General Banking Law. On this matter, the prospective Philippine Islamic banking regulatory framework has two options: (i) to allow cooperative banks with full Islamic banking license to engage in takaful, as an exception to the General Banking Law, or (ii) to restrict the offering of takaful to insurance cooperatives with limited Islamic banking functions. Under the Philippine Cooperative Code of 2008, cooperatives may engage in the business of insurance. This is reiterated in Section 190 of the Insurance Code.

\subsubsection{Tax Parity Treatment}

Takaful is one of two Islamic banking products that enjoy tax parity treatment, the other one being ijarah. This is because takaful has the same contractual arrangements as cooperative insurance, and this similarity in transaction design results in similar taxation.

Takaful has the same tax privileges as cooperative insurance under R.A. No. 9520, as follows: (i) exemption on income tax, (ii) exemption on VAT, (iii) exemption on other percentage taxes, (iv) exemption on donor's tax, (v) exemption on excise tax, (vi) exemption on DST, (vii) exemption from annual registration fee, and (viii) exemption from all taxes on transactions with insurance companies and banks. ${ }^{2}$

\subsection{Musharakah or mudarba}

\subsubsection{Nature of the Transaction}

A business proprietor who wants to set up a new venture, but without sufficient capital, can finance the venture either through equity investment by a capital partner. Banks are allowed to infuse equity in business ventures, and under proper conditions prescribed by law and regulation.

2 https://businessmirror.com.ph/cooperative-insurance/ (accessed on $5^{\text {th }}$ November 2018). 
Through musharakah, the bank infuses money in the business venture, and participates in the risks and rewards of business ownership. The bank and the business proprietor execute a "Profit and Loss Sharing Agreement", with the bank as contributor of capital and the proprietor as the manager and operator of the enterprise. The bank is not entitled to a pre-determined and guaranteed rate of return, otherwise it is construed as interest. The profit to the bank is dependent on the performance of the enterprise. Over time, the proprietor gradually purchases the equity interest of the bank in the enterprise until the bank is fully divested of any share or participation in the business.

The musharakah is, in effect, a partnership agreement. Unlike an ordinary partnership contract, however, musharakah involves an agreement for the client to gradually buy out the equity interest of the bank in the partnership.

A mudaraba, on the other hand, is similar in every way to a conventional partnership agreement, whereby one partner provides capital and another provides expertise and services. The partners agree on a profit-sharing ratio at the onset, but losses are borne by the capital partner. The difference between a mudaraba and a musharakah is that the former does not involve an arrangement on the part of one partner to buy out the share of the other partner in the partnership.

\subsubsection{Tax Parity Treatment}

The musharakah and mudaraba are legally identical to taxable partnerships, and are therefore taxed in the same way. A taxable partnership under the NIRC is treated similarly as a taxable corporation, its income being subject to the regular income tax rate of $30 \%$. The same treatment applies to musharakah and mudaraba.

The applicability of VAT and OPT depends on the type of business venture that the bank and the client will operate. Whether under a conventional partnership or under musharakah or mudaraba, the DST on certificates of profits under Section 177 of the NIRC applies, at P0.50 per P200, or fraction thereof, of the face value.

\subsection{Tawarruq}

\subsubsection{Nature of the Transaction}

A commodity trader who needs to finance the purchase of stock for his inventory normally resorts to a conventional line of credit, supported by trust receipts. Through a trust receipts transaction, the bank as trustor retains ownership or title over the commodity, while the client as trustee retains actual possession. The client has an obligation to sell the commodity to a vendee and turn over a portion of the proceeds of the sale to satisfy the loan taken out under the line of credit. If the commodity is not sold, the client has the obligation to place it in the possession of the bank. Failure to turn over the proceeds or the commodity is a criminal act punishable by law. This gives the bank an assurance that the loan taken out under the line of credit is repaid.

This conventional financing arrangement involves four parties: the commodity supplier, the commodity trader, the commodity buyer, and the bank. The supplier sells to the trader acting as a middleman, who in turn sells to the end-buyer. The trader finances the purchase of the commodity through a loan from the bank. Hence, four contracts are involved: (1) the contract of sale between the supplier and the trader, (2) the contract of sale between the trader and the end-buyer, (3) the 
contract of loan between the trader and the bank, and (4) the trust receipts transaction as security for the loan.

The tawarruq is the economic equivalent of this conventional arrangement. Since the interestbearing loan between the trader and the bank is prohibited by Shariah, the bank must purchase the commodity from the commodity supplier, just like in the murabahah. Subsequently, the bank sells the commodity to the trader at a profit and payable in the future. The trader then finally sells the commodity to the end-buyer. In contrast to the conventional line of credit supported by trust receipts, three contracts of sale are involved: (1) the sale from the supplier to the bank, (2) from the bank to the trader, and (3) from the trader to the end-buyer. The first and third contracts are spot sales, while the second contract is payable in the future to aid the financing needs of the trader.

The tawarruq is also called "reverse murabahah". This is because, under the murabahah, the sale between the vendor and the bank is a spot sale, and the subsequent sale between the bank and the vendee is an installment sale. On the other hand, in the tawarruq, the sale between the bank and the trader is payable in the future, while the subsequent sale between the trader and the end-buyer is a spot sale.

One important difference between murabahah and tawarruq is the contract of agency between the bank and client. Under murabahah, the bank appoints the client as an agent of the bank in purchasing the asset. Under tawarruq, the client appoints the bank as an agent in selling the asset to the end-buyer.

In the conventional line of credit supported by trust receipts, the trader in order to make profit must sell the commodity at a price higher than the cost of the commodity and the interest payable to the bank. In the tawarruq, the trader in order to make profit must sell the commodity at a price higher than the price payable to the bank, which has two components: the cost of purchase and the profit component. And the profit component, like in a murabahah, may be pegged at benchmark interest rates in conventional lines of credit.

\subsubsection{Differential Tax Treatment}

Due to the similarity of tawarruq and murabahah, tawarruq is taxed in the same manner as murabahah, and is therefore also differently taxed from conventional loan financing in the same manner as murabahah, as discussed in Section III.G.2.

\section{6 ljarah}

\subsubsection{Nature of the Transaction}

A client who needs an asset for business use, such as machinery, equipment, computers, vehicles, appliances, fixtures, and other movable property, but does not have sufficient funds to purchase the asset, may enter into a lease. Under an ordinary contract of lease, the lessor binds himself to allow the lessee to use and enjoy a property owned by the lessor for a specified time period, subject to the payment by the lessee of rental payments.

Leasing corporations offer what is called a "financial lease" to such clients. A financial lease is a contract of lease where the lessor purchases the asset upon the request of the lessee. The lessor retains title over the property during the period of the lease, but the period should be sufficiently long to cover the useful life of the asset. While the payment of rent is periodic, the total rental 
payment is almost equivalent to the capital outlay of the lessor in purchasing the asset, covering the lessor's cost of procuring the asset. The lease is also usually non-cancellable because it is the intention of the parties that the lessee will use the asset until it is fully depreciated. For these reasons, "substantially all the risks and rewards incidental to ownership of an asset are transferred to the lessee from the lessor."

The financial lease may be accompanied by an option in favor of the lessee to purchase the asset at the end of the period of the lease. The strike price of the option is just sufficient to cover the value of the asset after deducting depreciation. This is usually the case if the total rental payment is not sufficient to cover the capital outlay of the lessor in procuring the asset.

The ijarah is legally identical to a financial lease. It consists of the same contractual arrangement as the conventional financial lease offered by leasing corporations.

\subsubsection{Tax Parity Treatment}

The tax treatment of ijarah is the same as the treatment for financial lease. Financial lease yields rental income to the lessor bank or leasing corporation, subject to the regular income tax rate of $30 \%$.

The applicable Gross Receipts Tax is 7\% in the case of banks and non-bank financial intermediaries performing quasi-banking functions, under Section 121 of the NIRC, and $5 \%$ in the case of other non-bank financial intermediaries if the maturity of the lease does not exceed 5 years and $1 \%$ if otherwise, under Section 122 of the NIRC.

The DST on financial lease, on the other hand, treats financial lease as an obligation. Under Revenue Memorandum Circular (RMC) No. 46-2014, the BIR clarifies that financial leases are subject to the DST on debt instruments under Section 179 of the NIRC. The RMC provides:

"Although documents, transactions or arrangement under financial lease are not specifically mentioned under section 179 of the NIRC, as amended, it should be remembered that the imposition of the DST under such section of the NIRC, as amended covers all debt instruments. Therefore, being a nature of an obligation, financial lease is covered under such section of the NIRC, as amended."

Under Section 143 of the Local Government Code, municipalities may impose Local Business Tax on banks and other financial institutions, at a maximum of $50 \%$ of $1 \%$ of gross receipts from financial lease.

\subsection{Istisna}

\subsubsection{Nature of the Transaction}

A client who needs to finance an infrastructure or construction project, like a building or factory, may agree with the construction company to defer and schedule payments based on project milestones. The client may still not have enough funds to pay the company as payments become due in accordance with the contract. For this reason, it would still need additional financing from a bank through various modes of funding, including a simple contract of loan, or the issuance of debt instruments and corporate bonds. Whatever mode of conventional financing is available, any service involving an obligation to pay the principal amount with a fixed rate of interest to funder is prohibited under shar'iah. In conventional construction financing, the bank is not a party to the contract between the client and the construction company and has no equity interest in the asset being constructed. 
Under istisna, however, the bank becomes a party and intermediary. The bank purchases the asset from the construction company and sells the asset to the client. The bank does not earn interest, but from the spread between the buying and selling price of the asset under construction. The total cost of construction is fixed at the beginning of the project, subject to amendments in case of contingencies. The construction company and the bank are principal parties to the construction contract, and the bank in turn has a separate contract with the client whereby the latter undertakes to purchase the asset from the bank.

\subsubsection{Differential Tax Treatment}

The istisna is differently taxed from a conventional construction loan, in the same manner that the murabahah is differently taxed from a conventional mortgage-backed loan. And since both istisna and murabahah involve two sales transactions, with the bank simultaneously acting as buyer and seller, they receive the same tax treatment. First, the income of the bank under istisna is in the form of ordinary gain from dealings in ordinary assets, subject to the regular corporate income tax rate of $30 \%$ and to the rule on deferred payments under Section 49(A) and (B) of the NIRC. Second, the gain constitutes "profits from exchange", which are taxable at 7\% of the gross receipts under Section 121 of the NIRC.

\subsection{Salam}

\subsubsection{Nature of the Transaction}

Financing agricultural activities conventionally involve agricultural credit, which may be formal or informal. Formal agricultural credit involves private commercial banks, thrift banks, development banks, rural banks, and credit guarantee institutions as providers. Informal agricultural credit involves credit cooperatives, credit unions, paluwagans, and rotating savings and credit associations. Agricultural credit being in the form of a loan or an obligation with pre-determined interest, it is prohibited under shariah.

Salam, on the other hand, is a shariah-compliant form of agricultural financing whereby the client, who produces the agricultural commodity, sells the commodity to the bank before it is produced and delivered. The bank pays the client-seller outright for the commodity, and the client-seller undertakes to produce and deliver the commodity to the bank at a specified future date. Upon the arrival of that date, the client-seller delivers the commodity to the bank, and the bank sells the commodity to a third party in the market. Since the bank does not specialize in agricultural trading, it appoints the client-seller under a contract of agency to sell the commodity to a third party.

\subsubsection{Differential Tax Treatment}

Due to the similarity of salam and istisna, salam is taxed in the same manner as istisna, and is therefore also differently taxed from conventional loan financing as istisna, as discussed in Section III.G.2. 


\section{CONCLUSION}

Our analysis shows that the perceived tax inefficiency of Islamic banking transactions in the Philippines is more nuanced than what existing tax scholarship provides. While the claim is true in the case of murabahah, tawarruq, istisna, salam, and sukuk, it is not so in the case of ijarah, musharakah or mudaraba, and takaful. A bank offering financial lease is taxed in the same manner as an Islamic bank offering ijarah. A bank engaged in a partnership or joint venture agreement has almost equal income tax consequences as an Islamic bank offering musharakah or mudaraba. An ordinary insurance cooperative is also taxed in the same manner as an Islamic bank offering takaful.

\section{Bibliography:}

HANIF, M.: Differences and Similarities in Islamic and Conventional Banking. In: International Journal of Business and Social Sciences, Vol. 2, 2014, No. 2.

HANIF, M. - IQBAL, A. M.: Islamic Financing and Business Framework: A Survey. In: European Journal of Social Sciences, Vol. 15, 2010, No. 4.

HANIF, M.: Islamic Finance: Theory and Practice (December 27, 2010). Available at: https://ssrn.com/abstract=1731551 or http://dx.doi.org/10.2139/ssrn.1731551 (accessed on $5^{\text {th }}$ November 2018).

HANIF, M.: Introduction to Islamic Banking (June 9, 2012). Available at: https://ssrn.com/abstract=2223226 or http:// dx.doi.org/10.2139/ssrn.2223226 (accessed on $5^{\text {th }}$ November 2018).

ZAR ROKH, E.: Islamic Financing Arrangements Used in Islamic Banking (April 2, 2007). Available at: https://ssrn. com/abstract=978911 or http://dx.doi.org/10.2139/ssrn.978911 (accessed on $5^{\text {th }}$ November 2018).

SAFARI, M.: Are Sukuk Securities the Same as Conventional Bonds? In: Proceedings of Foundation of Islamic Finance Series, Second Conference, Kuala Lumpur, Malaysia, March 8-10. Kuala Lumpur, 2011.

SIDDIQI, Y. A.: Introducing Islamic Banking in New Markets (May 24, 2017). Available at: https://ssrn.com/abstract=2973166 or http://dx.doi.org/10.2139/ssrn.2973166 (accessed on $5^{\text {th }}$ November 2018).

SOLÉ, J. A.: Introducing Islamic Banks into Coventional Banking Systems. IMF Working Papers, 2007.

\section{Contact information:}

Rusell Stanley Geronimo rqgeronimo1@up.edu.ph SyCip Salazar Hernandez \& Gatmaitan

SyCipLaw Center

105 Paseo de Roxas

Makati City 1226

Metro Manila

Philippines 